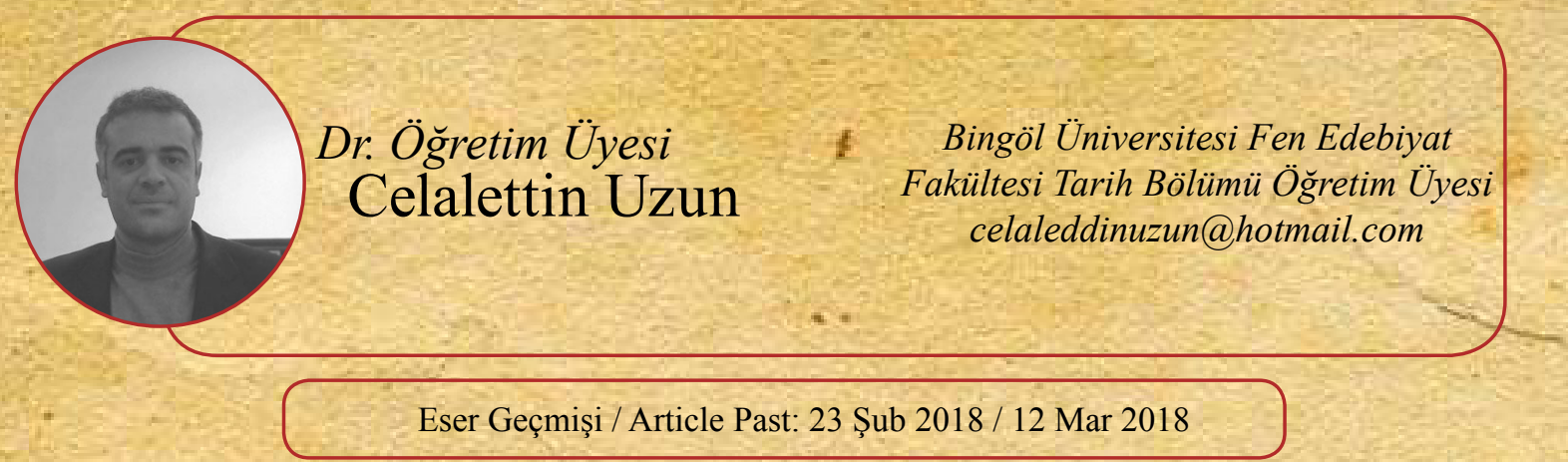

Araştırma Makalesi

DOI: $10.21551 /$ jhf.397826

Research Paper

Orjinal Makale / Orginal Paper

\title{
Muş Mütesellimi Alaaddin İsyanı
}

\author{
Rebellion of Alaaddin, Mütesellim of Muş
}

\section{ÖZET}

Osmanlı Devleti'nin, 16. yüzyılın sonlarına doğru İran ve Avusturya ile yaptığı savaşların uzun süreli olması devleti hem askeri hem de mali açıdan olumsuz etkilemiştir. 17. yüzyılda da devam eden bu durum içeride karışıklıklara neden olmuştur. Dolayısıyla 17. yüzyıl Osmanlı Devleti genelinde asayiş olaylarının had safhaya ulaştığı bir dönem olarak karşımıza çıkmaktadır. Bu yüzyılda Osmanlı ordusu bir taraftan batı ve doğu cephelerinde hâkimiyetini korumak için çabalarken, diğer taraftan da içerdeki âsilerle mücadele etmek zorunda kalmıştır. Savaşlar ve Anadolu'yu kasıp kavuran isyanlar nedeniyle askeri masrafların artması önemli boyutlarda bütçe açığı oluşturdu.

18. yüzyıla gelindiğinde de durum bundan farklı değildi. Osmanlı Devleti, bu yüzyılda da askeri açıdan oldukça masraflı seferlere girişmiştir. Savaşlar sebebiyle Anadolu'da meydana gelen otorite boşluğundan istifade eden kimi yöneticiler devlete başkaldırarak isyan etmişlerdir. Bu bağlamda 18. yüzyılın ortalarında Muş mütesellimi Alaaddin liderliğinde, Muş ve çevre şehir ve kasabalarda ortaya çıkan isyan ve eşkıyalık faaliyetleri devlet için oldukça tehlikeli bir boyuta ulaşmıştır. Alaaddin ve yandaşları Erzurum, Van, Bitlis ve Muş dolaylarında savunmasız pek çok yerleşim yerinde hâkimiyet kurmuşlar ve kendilerine karşı gelen ahaliyi öldürmüşlerdir. Nüfus ve gücünü gittikçe artıran eşkıya lideri, Muş ve çevresinde savunma amaçlı çok sayıda kale, palanga ve kuleler yaptırmıştır. Osmanlı Devleti'nin sınır güvenliğini tehlikeye düşüren ve ahalinin can ve mal güvenliğini ortadan kaldıran bu isyan ve eşkıyalık olaylarının bir an önce bastırılarak, kamu düzeninin yeniden tesis edilmesi devlet için büyük önem taşımaktaydı. Bu sebeple devlet isyan ve eşkıyalık faaliyetlerine sonlandırmak için Çeteci Abdullah Paşa'yı görevlendirmiştir. Yapılan muharebede eşkıya lideri Alaaddin ve destekçileri bozguna uğratılmış bölgede ehemmiyet ve huzur yeniden tesis édilmiştir.

Anahtar Kelimeler: Osmanlı Devleti, Muş, Mütesellim, İsyan, Eşkıyalık 


\section{ABSTRACT}

The long-term wars among Ottoman Empire, Iran and Austria to the end of 16 th Century affected the ottomans negatively in terms of military and finance. This situation which gone on in 17 th century caused the internal disorders. Thus, 17 th century is seen as a period in which anarchy reached at the advanced stage throughout the Ottoman Empire. While The Ottoman Army made effort in order to protect its sovereignty on the western and eastern front lines in this century, it had to struggle with the domestic rebels. The increase in the military expenses due to the wars and rebellions which oppressed Anatolia caused significantly budget deficits. The situation was the same in 18th century. Ottoman Empire made the expensive campaigns in terms of military in this century, too. Some administrators who resigned in the authority gap in Anatolia due to the wars revolted and rose against the state. The brigandage events due to the internal rebellions made disturbance in the security and peace atmosphere in the various places in Anatolia, and caused a significant danger in the state.

Within this context, the rebellions and brigandage events that arose in Mus province together with the cities and villages around it under the leadership of Alaaddin Mütesellim of Mus in the 18th century became dangerous for the Empire. Alaaddin and his followers established dominance in many indefensible settlements of the territories of Erzurum, Bitlis, Van and Muss, and killed many inhabitants who disobey them. The brigand leader who was getting increased his influence and power day by day constructed many fortresses, pulley blocks and towers in and around Mus for defence. It was very significant for the Ottoman Empire to constitute the public order repressing immediately the rebellions and brigandage events that jeopardised the border security of Ottoman and that abolished the safety of life and property of the public. That's why, Guerrilla Abdullah Pasha was authorised to terminate these bellions and brigandage events. At the result of the war, Alaaddin the brigand leader and his supporters were defeated and hereby safety and peace could be constituted again.

Key Words: Ottoman Empire, Muş, Mütesellim, Rebellion, Brigandage

\section{GíRiş}

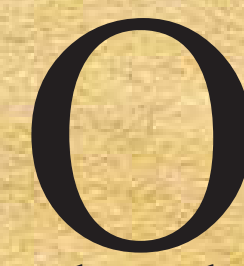

smanlı Devlet'inde, 16. yüzyılın ortalarından başlayarak 17. yüzyılda devam eden ekonomik sarsintı toplum ve devlet hayatını olumsuz yönde etkilemiştir. Bu dönemde yapılan savaşların uzun süreli olması devleti mali bir darlığa sürüklemiștir. Bu sebeple tekâlif-i örfiye veya tekâlif-i divaniye olarak adlandırılan geçici vergiler sürekli hale getirilmiş ve miktarı da artırılmışır. Öte taraftan devlet iktisadi darlıktan kurtulmak için bir kısım tımar topraklarını mukataaya dönüștürerek iltizama vermiştir. Ancak bu durum tımar sisteminin bozulmasına ve vergileri ödemekle yükümlü olan reaya üzerinde dayanılması güç bir külfete neden olmuştur ${ }^{1}$. Bir taraftan ağır vergi yükümlülüğü altında ezilen halk, diğer taraftan idarecilerin kanun dışı vergi taleplerinden dolayı baskı ve zulümlere de uğramıştır.

1 Mustafa Akdağ, Türkiye Halkının Dirlik ve Düzenlik Kavgası Celâlî Isyanları, İstanbul, 2017, s.89-90. 
Merkezden uzak bazı yerlerde halktan kanun dişı vergi toplayarak devlet otoritesine karşı gelen bu idarecilerin bir kısmı aynı zamanda eşkıyalık olaylarına da karışmışlardır. Halkın canına ve malına kast eden bu yöneticiler yüzünden Anadolu' da asayiş ve güvenlik ortamı büyük oranda zedelenmiştir. Hatta isyan eden bazı valiler, başına buyruk hareket eden bir kısım yöneticileri de etrafına toplayarak, merkezi hükümeti tehdit etmişlerdir².

Osmanlı Devletinde, 17. yüzyılda isyan ve eşkıyalık hareketlerinin çıkmasına neden olan problemlerin giderilmemesi sebebiyle bu hareketler 18. yüzyilda da sürmüștür. 17. yüzyılda olduğu gibi 18. yüzyılın başlarından itibaren devleti mali açıdan zorlayan seferler devam etmiştir. Özellikle Anadolu'da bulunan çoğu yönetici bu seferlerden dolayı sorumlu oldukları bölgeyi terk etmişlerdir. Bu durum merkezi otoritenin zayıflamasına neden olmuştur. Dolayısıyla Anadolu'nun çeşitli yerlerinde meydana gelen otorite boşluğundan istifade eden bir kısım idareciler kanunlara karşı gelerek, halk üzerinde büyük zorbalıklarda bulunmuşlardır ${ }^{3}$. Hatta bu yüzyılda mal sevdalısı vilayet, sancak ve kaza yöneticilerinden kaynaklanan eşkıyalık olaylarında büyük bir artış olduğu gözlenmektedir

$\mathrm{Bu}$ çalışmada Muş sancağı hakkında kısa bir bilgi verildikten sonra İran sınırına yakın bir bölgede, bilhassa Muş ve çevre şehir, kasaba ve köyleri büyük oranda etkileyerek toplumsal buhranlara yol açan isyan ve eşkıyalık faaliyetlerine değinilecektir. Bu suretle 18. yüzyılın ortalarında devlet için oldukça tehlikeli bir boyuta ulaşan Muş mütesellimi Alaaddin'in liderliğini yaptığı eşkıyalık faaliyetleri hakkında bilgi verdikten sonra devletin bu isyanı bastırmak için aldığı tedbirlerden bahsedilecektir. Diğer taraftan Alaaddin' in isyanı bastırmak için bölgeye sevk edilen askeri birliğe karşı savunma amaçlı aldığ 1 tedbirler de anlatılacaktır. Öte yandan bu isyanda Alaaddin'e destek olan Hakkâri'den Tatar Han, Bitlis hâkimi Burhan Han, Malazgirt beyi Nuh ve Mahmudi ahalisinden Mirhab adlı beylere karşı merkezi hükümêt kuvvetlerinin verdiği mücadeleye dair bilgi verilecektir.

\section{MUŞ MÜTESELLIMI ALAADDIN ISYANI}

Muş, coğrafi olarak Doğu Anadolu Bölgesi’nin Yukarı Murat-Van Bölümünde bulunmaktadır. Doğuda Ağrı ve Bitlis, batıda Bingöl, kuzeyde Erzurum, güney ve güneybatıda ise Bitlis, Diyarbakır ve Batman illeriyle komşu olan şehir, yaklaşı $8116 \mathrm{~km}^{2}$ alanı kapsamaktadır ${ }^{5}$. Şehir, Fırat nehrinin en önemli kolu olan Murat ırmağı ile Karasu'nun geçtiği bir ovanın güneyinde kurulmuştur ${ }^{6}$. Muş ve çevresinde zengin su kaynakları ile verimli ovaların olması çok eski dönemlerden itibaren bölgenin önemli bir yerleşim merkezi olduğunu göstermektedir. Zira tarihi süreç içerisinde bölgede birçok uygarlık hüküm sürmüştür.

Milattan önce bölgede Hititliler, Urartular, Asurlar ve Romalılar hâkimiyet

2 Mustafa Akdağ, "Genel Çizgileriyle XV̊II. Yüzyıl Türkiye Tarihi”, Ankara Üniversitesi Dil ve Tarih-Coğrafya Fakültesi Tarih Bölümü Tarih Araştırmaları Dergisi, 4/6-7, Ankara, 1966, s. 225.

3 Selim Özcan, “XVIII. Yüzyıl Canik (Samsun) Sancağında Eşkıyalık Hareketler”, Osmanlı'dan Günümüze Eşkıyalık ve Terör, Editör, Osman Köse, Samsun, 2009, s. 85.

4 Şaban Bayrak, Anadolu'da Eşkıyalık Olayları (XVIII. Yüzyılın İlk Yarısında 1700-1750), İstanbul, 2015, s. 71-96.

5 Mehmet Emin Sönmez, "Muş İlinde Nüfus Hareketlerinin Nedenleri ve Sonuçları", Türk Coğrafya Dergisi, S. 55, İstanbul, 2010, s. 45-46.

6 Besim Darkot, "Muş", İslam Ansiklopedisi, C. 8, Eskişehir, 1997, s. 744. 
kurmuşlardır. Milattan sonra Roma devletinin iki ayrılmasıyla birlikte Muş ve çevresi Bizans egemenliğine geçti. Ancak daha sonra Bizans'tan bölgeyi İranlılar aldı. Sonrasında ise Hz. Ömer döneminde Araplar, bölgede ki İran egemenliğine son verdiler. İlerleyen żamanlarda Arap, Bizans ve İran devleti arasında ki mücadele nedeniyle bölge sık sık el değiştirmiş̧ir?.

Malazgirt zaferinden sonra Selçukluların Muş ve çevresini ele geçirmeleriyle, bölge Müslüman Türk unsurlarının hâkimiyetine girmiştir. Yavuz Sultan Selim'in Çaldıran'da Şah İsmail kuvvetlerini mağlup etmesinden sonra Anadolu'nun Osmanlı hâkimiyetine geçmesiyle Muş ve çevresi de alındı.

Osmanlı Devleti'nin idari taksimatında Muş, Van Eyaletine bağl1, bir sancak merkez olarak gösterildiği gibi, yine Van Eyaletine bağlı Bitlis hükümetinin bir nahiyesi olarak da gösterilmiştir'. $1515^{\prime}$ ten 1550'li yıllara kadar Bitlis sancağının bir nahiyesi olan Muş, uzun bir süre müstakil sancak olarak idari teşkilatta yer almıştır ${ }^{9}$. Fakat bir süre sonra tekrar nahiye statüsüne düşürüldügü görülmektedir. Zira 17. yüzyılın ortalarında Muş, Bitlis Sancağına bağlı bir nahiye olarak da idare edilmiştir ${ }^{10}$. 18. yüzyılın ikinci yarısında da Muş'un, Van Eyaletine tabi bir nahiye olduğu anlaşılmaktadır ${ }^{11}$. Nahiyenin idaresinden sorumlu olan mütesellimin ${ }^{12}$ atamasında ise Bitlis Hanı etkiliydi. Nitekim 1747 tarihli bir belgede Muş nahiyesine Bitlis Hanı tarafından mütesellim olarak Alaaddin'in görevlendirildiği ifade edilmektedir ${ }^{13}$. Dolayısıyla 18. yüzyılın ikinci yarısına doğru Muş Sancağının Van Eyaletine tabi Bitlis hükümetinin bir nahiyesi olduğu söylenebilir. Fakat Bitlis hanedanının ortadan kaldırılmasından sonra, Muş, Erzurum Eyaletine bağlı sancak merkezi olmuştur ve Bitlis, Muş'a bağlanmıştır ${ }^{14}$.

Alaaddin mütesellim olarak vazifelendirilmeden önce, 1738 tarihli bir belgeden anlaşıldığı üzere Bitlis Han'ı Süleyman Bey'in kethüdası olarak görev yapmaktaydı. Ancak Alaaddin, Muş mütesellimi Mirza ve Hal Ömer oğlu Mehmed ile birlikte bu tarihte bölgede eşkıyalık faaliyetlerinde bulundukları anlaşılmaktadır. Nitekim bunlar yanlarına topladıkları bin kişilik bir kuvvetle Erzurum'a bağlı Hınıs kazasının Kızıl Ahmed ve Halil Çavuş karyelerin de içinde bulunduğu bir kısım köylere saldırarak halkın mallarını gasp ettikleri gibi canlarına da kastetmişlerdir. Belgeden anlaşıldığına göre şakiler köylerden iki bin yüz karasığır ve camus, üç bin seksen yedi koyun, iki yüz altmış at ve kısrak, üç yüz yetmiş kovan ile birlikte sekiz yüz kuruş nakit akçe ve mevcut hanelerin eşyalarını almışlardır. Bunun üzerine köy sakinlerinden bir miktar süvari, gasp edilen mallarını geri

7 M. Salih San, Doğu Anadolu ve Muş'un İzahlı Kronolojik Tarihi, Ankara, 1966, s. 127-165.

8 Besim Darkot, "Muş", MEB İslam Ansiklopedisi, s. 746.

9 Başbakanlık Osmanlı Arşivi (BOA), BOA.TD. 189, s. 17-24.

10 Orhan Kılıç, "Muş Sancağı Dirlikleri”, Fırat Üniversitesi Sosyal Bilimler Dergisi, 9/1, Elazı̆̆, 1999, s. 158-160.

11 "Van Eyâletine tâbi" Muş nâhiyesinde" BOA.C.DH.210.

12 Beylerbeyi ya da sancakbeyi görev mahallinde bulunmadıkları zaman, onlar adına bölgeyi idare eden yöneticiye mütesellim denilmektedir. Beylerbeyi veya sancakbeyi tarafindan atanan mütesellimin başkentten bir fermanla onaylanması gerekmekteydi. Mütesellimler beylerbeyi ve sancakbeyinin vekili oldukları için onların tüm yetkilerine sahiptiler. Tanzimat Fermanı ile devlette yeni bir düzenlenmeye gidilmesiyle bu kurum kaldırılmıştır. Bilgi için bkz. Yücel Özkaya, "Mütesellim", DIA , C. 32, İstanbul, 2006, s. 203-204.

13 BOA.C.DH.270; Mühimme Defteri (MHM), 153, s. 117/b.2.

14 Besim Darkot, "Muş”, İslam Ansiklopedisi, s. 746. 
almak amacıyla eşkıyaların peşine düşmüştür. Ancak eşkıyalarla girişilen muharebede on üç kişi ölmüş ve birçok kimse de yaralanmıştır. Alaaddin ve diğer eşkıyaların cezalandırılması için Erzurum Valisi el-Hâc Ahmed Paşa vazifelendirilmiştir ${ }^{15}$. Eşkiyalıkla suçlanan elebaşların cezalandırıldığına dair elimizde bir bilgi bulunmamaktadır. Ancak 1747 tarihli bir belgeden anlaşıldığına göre Alaaddin'in Bitlis Hanı tarafından Muş'a mütesellim olarak görevlendirilmesi ${ }^{16}$, Osmanlı Devleti'nin eşkıyalık olaylarına son vermek için isyancı grubun liderleriyle anlaşmaya vardığını göstermektedir. Zira Osmanlı Devleti, üzerine göndẹrmiş olduğu askeri kuvvetle yakalayamadığı bazı eşkıya elebaşlarına bir takım mansıp ve makamlar teklif ederek onların isyanlarına son vermesi sıklıkla müracaat ettiği bir yöntemdi ${ }^{17}$. Eşkıya liderlerinin çoğu da daha iyi bir makam elde etmek için isyan ediyorlardı. Mesela sancakbeyinin hizmetine girmiş veya kethüdalık yapmış ya da mütesellim olarak hizmet görmüş eşkıya liderleri daha yüksek, bir mevkide görev almak istiyordu ${ }^{18}$. Muş ve çevre şehirleri etkileyen bu isyan girişimi ayrıca İran'a yapılacak seferlerin güvenliğini de büyük oranda etkiliyordu. Bu yüzden devlet isyan ve eşkıyalık olaylarını biran önce sona erdirmek için Alaaddin'e Muş mütesellimliğini vermiştir. Ancak Alaaddin Muş mütesellimi olarak görevlendirilmesine rağmen ya daha yüksek bir konum elde etmek için ya da İran ile işbirliği yaptığından dolayı isyan faaliyetlerini arttırarak devam ettirmiş adeta eşkıyalık boyutunda faaliyetler içerisinde olmuştur. Nitekim 1747 yılında eşkıya lideri Bitlis ve Erzurum taraflarına saldırmıştır. Özellikle kışşartlarından istifade ederek Erzurum hududu dâhilinde bulunan sancak ve nahiyelerde bulunan ahaliye büyük zarar vermiştir. Bunun üzerine Bitlis Hanı, Alaaddin'in eşkıyalık faaliyetlerine son vermek için harekete geçmiştir. Ancak başarılı olamamış üstelik bu durum Alaaddin'in kuvvetini ve nüfuzunu daha da artırmasına neden olmuştur. Hatta bölgede bazı palanga ${ }^{19}$ ve kuleler yaptırmıştır ${ }^{20}$. Bu sebeple Erzurum Valisi İbrahim Paşa Alaaddin ve avenesini cezalandırmak için görevlendirilmiştir. Fakat Alaaddin ve arkadaşları kış şartlarından istifade ederek firar etmeyi başarmışlardır. $\mathrm{Bu}$ gelişmelere binaen Alaaddin'in yakalanması için eski Adana Valisi Çeteci Abdullah Paşa $^{21}$ vazifelendirilmiştir. Ancak şiddetli kış sebebiyle yakalanması mümkün olamamıştır. O yüzden Bitlis hanı Burhan ve Bitlis kadısı ile bir kısım ulema, ayan ve yerli ocak ağaları ile Muş ahalisi, merkezden Alaaddin'in bağışlanmasını ve gelip hanesine yerleşerek kendi halinde yaşamını sürdürmesini talep etmişlerdir. Ayrıca eşkıyalara ait çeşitli ebatlarda dört adet top da devlet görevlilerine teslim edilmiş ve bunlar Muş kalesine kaldırılmıştır. Öte taraftan ahali Alaaddin ve avenesinin tekrardan isyan etmeyeceğine dair taahhütte bulunmuşlar ve bunlardan eşkıyalık faaliyetleri sadır olursa bin kuruşluk bir parayı devlet hazinesine ödeyeceklerini nezir ${ }^{22}$ etmişlerdir. Bölgenin durumu, siyasal ve sosyal gelişmeler

15 MHM, 145 , s. $184 /$ b.3.

16 BOA.C.DH.270; MHM, 153, s. 117/b.2.

17 Süleyman Demirci, Hasan Arslan, Osmanlı Türkiye 'sinde Eşkıya, Devlet ve İsyan, İstanbul, 2012, s. 110.

18 Karen Barkey, Eşkiyalar ve Devlet Osmanlı Tarzı Devlet Merkezleşmesi, (Çev. Zetnep Altok), İstanbul, 2011, s. 203.

19 Palanga ağaç kütüklerinden koruyucu bir çitle çevrili basit bir yapı olarak tanımlanmaktadır. bkz. Veysel Göger, 16. Yüzyıl Osmanlı Kale Kuşatmaları (Stæateji, Taktik, Kuşatma Aşamaları ve Teknolojisi), Marmara Universitesi Türkiyat Araştırmaları Enstitüsü (Basılmamış Doktora Tezi), İstanbul, 2014, s. 62-63.

20 BOA.C.DH.270; MHM, 153, s. 117/b.2.

21 Çeteci Abdullah Paşa yapılan bir çalışmada sehven Çeneci Abdullah Paşa olarak ifade edilmektedir bkz. Şaban

I Bayrak, Anadolu'da Eşklyalık Olayları (XVIII. Yüzyılın IIlk Yarısında 1700-1750), İstanbul, 2015, s. 93.

22 Osmanlıda kamu düzenini sağlamak için uygulanan bu yöntem hakkında ayrıntılı bilgi için bkz. Cemal Çetin, "Kamu Düzeninde Alternatif Bir Yöntem: Nezir" Uluslararası Sosyal Araştırmalar Dergisi, 8/36, 2015, s. 287310. 
göz önüne alınmış ve neticede 1748 yılında gönderilen bir fermanla ahalinin bu isteği kabul edilmiştir ${ }^{23}$.

Ne var ki korunaksız bölgelerde halkın malına, canına ve ırzına zarar vererek eşkıyalık faaliyetlerinde bulunan ve devlet gücüyle karşılaştıklarında firar edip saklanmayı tercih eden bu kişilerin af edilmesi sorunu çözmemiștir. Nitekim sonraki dönemlerde Alaaddin ve taifesinin eşkıyalık faaliyetleri devam etmiştir. 1754 tarihli bir belgeden anlaşıldığına göre, bunlar Van, Bitlis ve Muş'un etrafinda bulunan savunmasız köylere saldırarak ahalinin hayvanları ile mallarını gasp ettikleri gibi ırzlarına ve canlarına da kastetmişledir ${ }^{24}$.

Bölgede eşkıyalık faaliyetlerine son vermek için 1754 yılının ilkbaharında Çeteci Abdullah Paşa Erzurum Valiliğine atanarak görevlendirilmiştir ${ }^{25}$. Eşkıyaların yakalanıp gerekli cezaya çaptırılması amacıyla Çeteci Abdullah Paşaya yardım etmesi için Van Muhafizı es-Seyyid Mustafa Paşa da vazifelendirilmiştir ${ }^{26}$. Öte taraftan bölgede Muş mütesellimi Alaaddin ile birlikte hareket ederek isyan eden başka idareciler de vardı. Bunlardan en dikkat çekenlerden biri Bitlis hanı Burhandı. Zira Burhan Han, Alaaddin'in daha önce devlet tarafindan affedilmesi husussunda önemli rolü olmuştur ${ }^{27}$. Burhan Han'ın dışında Malazgirt Beyi Nuh, Hakkâri bölgesinden Tatar Han ve Mahmudi ${ }^{28}$ ahalisinden Mihrab adlı şaki liderleri de Alaadin'e destek vermişlerdir ${ }^{29}$.

Eşkıya lideri Alaaddin ile birlikte isyan ve eşkıyalık faaliyetlerinde bulunan Hakkari bölgesinden Tatar Han ve Mahmudi ahalisinden Mihrab'ın İran hududuna yakın bölgelerde görev yapmaları (bkz. Harita 1) İran'ın eşkıya liderleriyle işbirliği içinde olduğu söylenebilir.

23 BOA.C.DH.98; MHM, 153, s. 114/b.2; MHM, 153, s. 115/b.3; BOA.A.AMD.8; BOA.A.AMD.2.

24 BOA.C.DH.65.

25 BOA.C.DH.194.

26 BOA.C.DH.210.

27 BOA.A.AMD.8.

28 Evliya Çelebi Mahmudi'nin Van'ın doğusunda yalçın dağlar içerisinde bir bölge olduğunu ve burasıyla Acem arasında sadece Şah Gediği adında bir dağın olduğunu ifade eder. Bkz. Evliya Çelebi b. Derviş Mehemmed Zılli, Evliya Çelebi Seyahatnâmesi, 4. Kitap, (Haz. Seyit Ali Kahraman-Yücel Dağl1), İstanbul, 2001, s. 118.

29 BOA.C.DH.65; BOA.C.DH.210; BOA.C.DH.306; BOA.C.AS.233. 
Harita 1: Eşkıya Liderlerinin İsyan Faaliyetlerinde Bulundukları Bölgeler

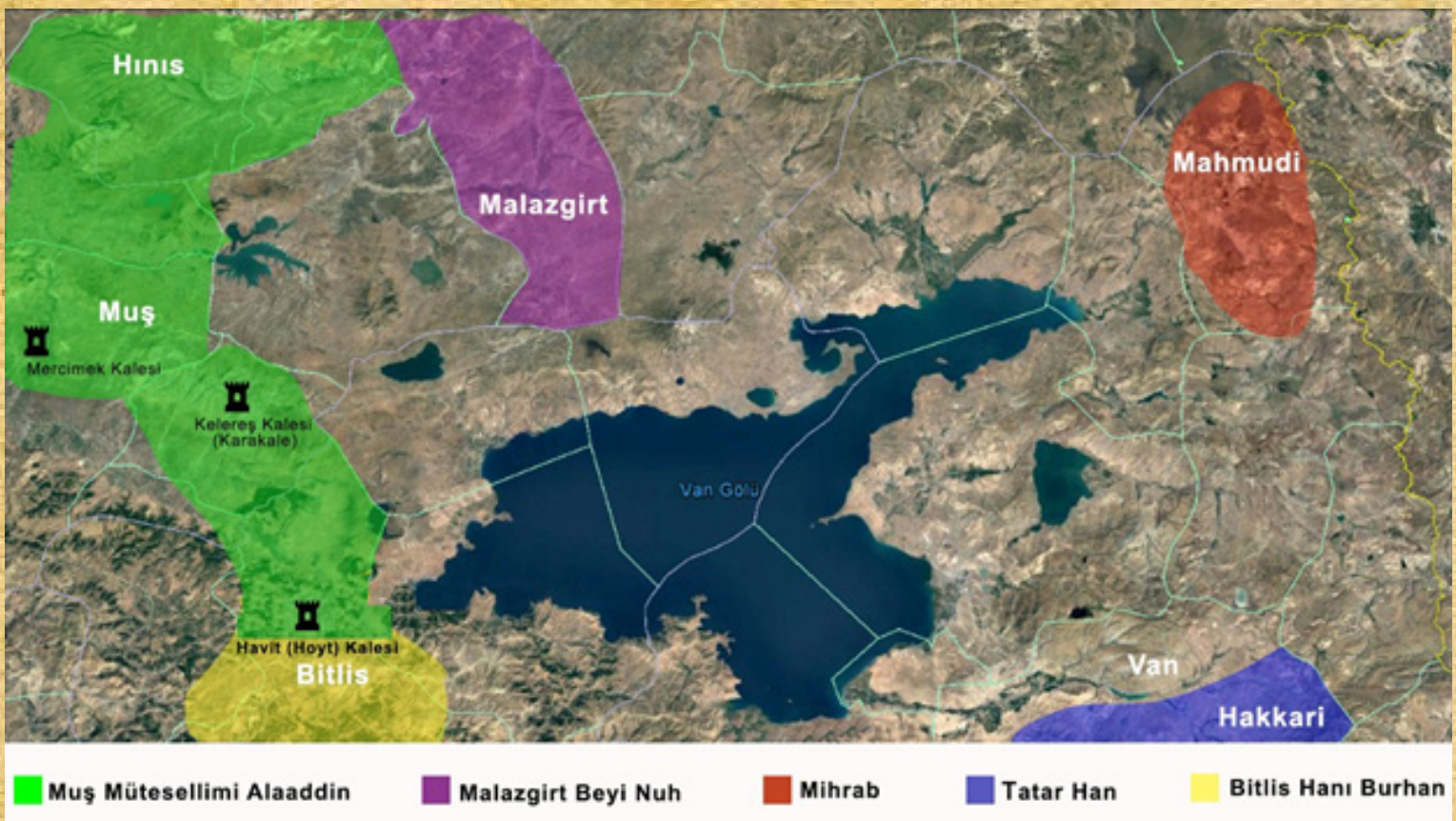

Nitekim Osmanlı sınırlarının İran hududuna kadar genişlemesi 16. yüzyıldan itibaren Osmanlı ile İran arasında yaşanan sınır ve aşiret tartışmaları sürekli olmuştur. Bu sebeple her iki devlet bölgedeki aşiret liderlerini kendi yanlarına çekmeye çalışmıştır. Bu bağlamda İran da bazı aşiret liderlerini elde etmek için mansıplar vermiştir. Bu durum Osmanh Devleti'ni rahatsız etmiştir ${ }^{30}$.

Alaaddin ve diğer eşkıya liderlerinin isyan etmeden önce iyi bir planla örgütlendikleri ve gerekli hazırlık yaptıkları anlaşılmaktadır. Alaaddin isyanı bastırmak amacıyla üzerine gönderilecek askerler için savunma maksadıyla Muş ve çevresinde kaleler yaptırmıştı. Kalelerden biri Muş ovasına inen Çarihor (Çarpehor) adlı vadide kesme taşlardan inşa edilmişti. Diğer bir kale ise Muş kasabasına beş saatlik bir vadi üzerinde yaptırılan Mercimek Kalesiydi. Bu kale güçlü bir kaya üzerinde üç katlı sur şeklinde mermer taşlardan yaptırılmıştı. Mercimek kalesi üç yüz zirâ 'dan ${ }^{31}$ fazla bir alanı kaplamaktaydı. Kalenin içinde yine mermer taşlarından doldurulan dört adet top tabyası vardı. Ayrıca çevreyi gözetlemek için kaleye dört adet kule de yaptırılmıştı.

Mercimek kalesini takviye için kalenin varoşlarında bir kule daha yaptırılmış ve yine kalenin etrafına derin hendekler de kazılmışıtır. Öte taraftan Alaaddin'in kalenin etrafında bir şehir kurmak arzusunda olduğu da anlaşılmaktadır.

Alaaddin bu kalelerin dışında Muş kasabasının batı tarafında yaklaşık altı saat uzaklıkta yer alan Kutyan (Gotyan) adlı bir kale ile yine Muş kasabasına üç saat uzaklıkta

30 Sitkı Uluerler, Osmanlı-Iran Sinır ve Aşiret (1800-1854), Ankara, 2015, s. 175.

31 Osmanlıda yirmi dört parmaklık bir uzunluk ölçüsü olup diğer bir ismi arşındır. Uzunluk ölçüsünün miktarında bölgesel farklıliklar da vardır. Zeki Pakalın, Osmanlı Tarih Deyimleri ve Terimleri Sözlüğü, C. 4. İstanbul, 1983, s. 663,664; Mehmet Ali Ünal, Osmanlı Tarih Sözlügü̈, İstanbul, 2012, s. 749. 
olan ve Murat nehri üzerinde bulunan dağların arasında siyah bir kaya üzerinde başka bir kale de yaptırmıştı. Ayrıca Muş'un doğu tarafında bulunan ve Muş'a on dört saat uzaklıkta olan Kelereş' ${ }^{32}$ yaptırmıştı. Bunların yanı sıra Muş şehrinin güney tarafında, Bitlis şehrine yakın bir mahalde ve yüksek dağların arasında Havit (Hoyt) kalesini de inşa ettirmiştir.

Alaaddin yaptırdığı bu kalelerin her birinin içine de yeterli miktarda barut, kurşun ve çeşitli ebatlarda toplar yerleştirmiştir. Ayrıca kalelerin içine eşkıyalardan oluş̧an bölükbaşları ve tüfekçiler doldurmuştu. Diğer taraftan bazı köylerde de bölgede köşk olarak tabir edilen yirmi kadar palanga inşa ettirmişti. Bu suretle Muş ve etrafındaki şehir kasaba ve köyler için büyük bir tehlike oluşturan Alaaddin ve adamları gittikçe güçlenmekteydi. Nitekim bölgedeki, liva, kasaba ve köyleri istila ederek, kendilerine karşı gelenleri öldürüyorlard $1^{33}$.

Erzurum Valisi Çeteci Abdullah Paşa devlet için oldukça tehlikeli bir hal almaya başlayan isyan hareketini bastırmak için gerekli hazırlıkları yaptıktan sonra 9 Ağustos 1754 tarihinde Erzurum'dan Mercimek Kalesi’ne doğru harekete geçmiştir. 21 Ağustos Çarşamba günü Mercimek Kalesi önüne gelerek burayı muhasara etmiş̧ir. Ancak Alaaddin Mercimek Kalesi'nde dört yüz kadar tüfekçi eşkıyasına bırakarak, kendisi Mercimek Kalesi'ne on beş saat mesafede olan Havit (Hoyt) adlı kaleye sığınmıştır. Çeteci Abdullah Paşa Mercimek Kalesi'ni muhasara etmiş ve ele geçirmek için kalenin etrafinda metrisler açmıştır. Kale ve kulelerini top, tüfek ve humbaralar ile dövmüştür. Kalenin içindeki eşkıyalar bu saldırılara ancak iki gün dayanabilmiştir. Netice itibariyle 23 Ağustos Cuma günü kaledeki eşkıyalar aman dileyerek kaleyi teslim etmişlerdir ${ }^{34}$. Önceki asırlardan beri Osmanlıların kuşatma savaşlarında uzmanlaşmas $1^{35}$ ve merkezi hükümet tarafından görevlendirilen fazla miktardaki eyalet askeri ile kale muhasarasında kullanılan top ve sair ağır silahlar, çevreye göre yüksek bir mevkide bulunan (bkz. Resim 1) ve muhasara öncesi tahkim edilen Mercimek Kalesi'nin iki gün gibi kısa sürede ele geçirilmesini açıklayan etmenler olarak değerlendirilebilir.

Mercimek Kalesi'nin ele geçirilmesinden sonra askerler Alaaddin'in bulunduğu Havit (Hoyt) kalesiüzerine yürümüş ve burada yapılanmuharebe de eşkıyaların çoğu öldürülmüştür. Ancak Alaaddin, oğulları ve bir kısım avenesi kaçarak canlarını kurtarabilmişlerdir. Bu haber bölgede yayılınca diğer kalelerde bulunan eşkıyalar da kaleleri boşaltıp her biri bir yere kaçmıştır. Çeteci Abdullah Paşa'da, Alaaddin'e ait başta Mercimek Kale olmak üzere diğer kaleleri ve köylerde yaptırılan palangaları tamamıyla yıkarak kullanılamaz hale getirmiştir. Mercimek Kale'de ele geçirilen dört tane şakalos ${ }^{36}$ topları ve dört tane zenburekleri ${ }^{37}$ ve bir miktar barut ile altı yüz batman kurşun Erzurum Kalesi'ne gönderilmiştir.

32 Yüksek bir tepe üzerinde hâkim bir konumda bulunan kalenin altında kurulan yerleşim yeri adını kaleden almıștır. Halk arasında Kelereş köyü ve kalesi olarak anılan bu yerleşim yerinin ismi Karakale olarak da bilinmektedir.

33 BOA.C.DH.65.

34 BOA.C.DH.65.

35 Konuyla ilgili olarak bkz. Veysel Göger, “Askerî Devrim Kuramı ve XVI. Yüzyıl Osmanlı Kale Kuşatmaları”, Dîvân: Disiplinlerarası Çalışmalar Dergisi, C. 22, S. 42, İstanbul 2017/1, s. 67-106.

36 Kaz yumurtası şeklinde gülle atan bir çeşit küçük toptur. Çakaloz, şakaloz veya şakloz gibi farklı isimlerle de anılmaktadır. Salim Aydüz, Tophane-i Amire ve Top Döküm Teknolojisi, Ankara, 2006, s. 400. Ayrica bkz. Gabor Agoston, Barut, Top ve Tüfek Osmanlı Imparatorluğu'nun Askeri Gücü ve Silah Sanayi, İstanbul, 2006, 124-125.

37 Havan ile taşınabilen eski küçük toplara verilen addır. Bu toplara zenberekte denilmektedir. bkz. M. Zeki Pakalın, Osmanlı Tarih Deyimleri ve Terimleri Sözlüğü, C. 3. İstanbul, 1983, s. 652. 
Diğer taraftan Malazgirt Beyi Nuh adlı şakinin üzerine de asker gönderilmiştir. Ancak Nuh da bir yolunu bularak kaçmayı başarmıştır. Bölgede Nuh'a ait olan iki kale yıkılarak kullanılmaz hale getirilmiştir. Öte taraftan Mahmudi ahalisinden olan Mihrab ve Tatar Han'ın üzerine de asker sevk edilmiştir. Mihrab yakalanarak cezalandırılmıştır. Fakat Tatar Han göçer taifesinden olduğu için askerin üzerine geldiğini önceden haber alınca Hakkari dağlarına sığınmıştır. Zira Hakkari dağları belgede ifade edildiği üzere kış mevsiminde saklanmak ve barınmak için uygun bir yerdi ${ }^{38}$. Öte taraftan şakilerden olan Bitlis hanı Burhạn da kaçmayı başarmıştır.

\section{Resim 1: Mercimek Kale}

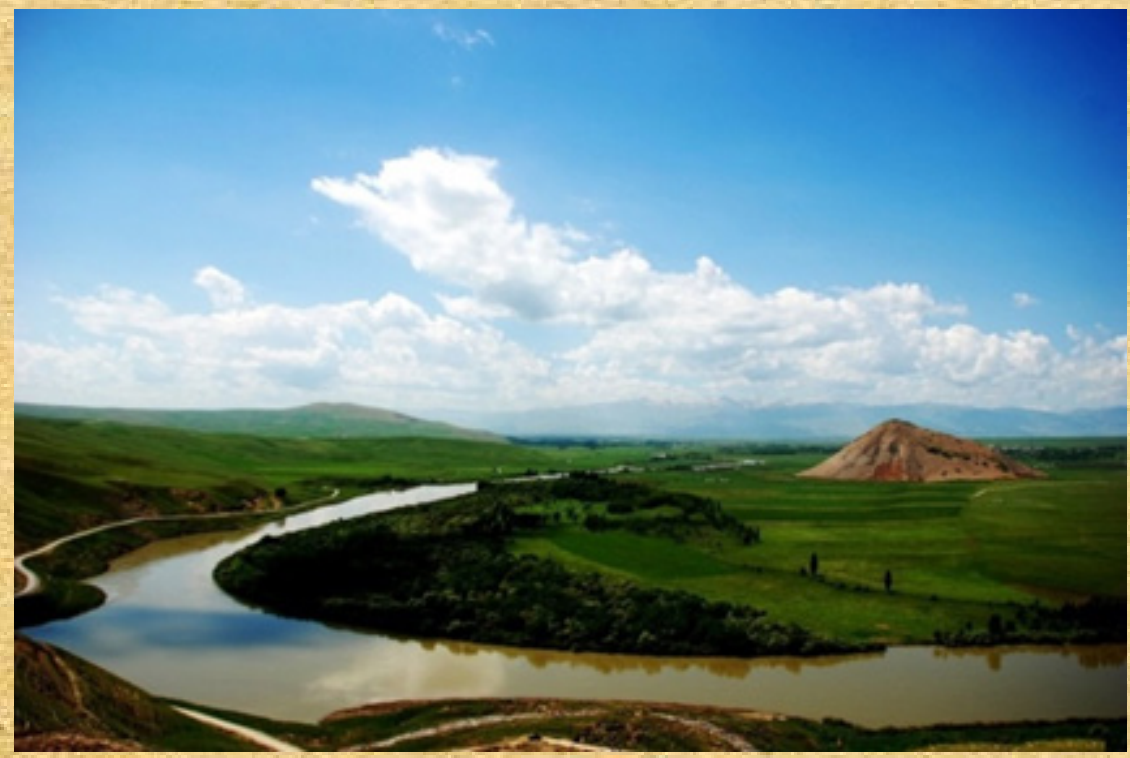

(Kaynak: Hidayet Kara)

Resim 2: Kelereş Kale (Karakale)

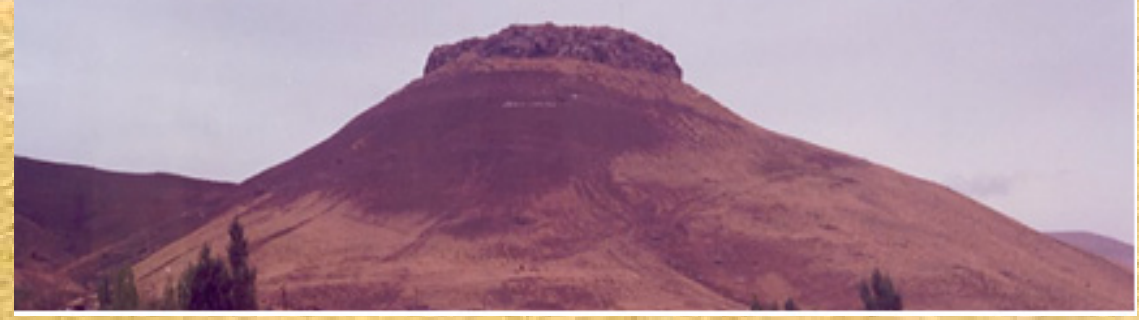

38 “Hakkari dağları mahalle-i meştâ olub hengâm-1 şitâ dahi karîb olmağla....” BOA.C.DH.65. 
Halkı usandıran, mal ve mülkünü her firsatta yağmalayan eşkıya ve elebaşları bozguna uğratıldıktan sonra tekrardan Muş ve çevresindeki şehir ve kasabalarda ehemmiyet ve huzur ortamı sağlanmıştır. Hayatın normalleşmesiyle ahali rahatlamış, ekonomik ve tarımsal faaliyetler yeniden canlanmıştır. Fakat bölgenin coğrafi yapısı sebebiyle bölgede geniş ve saklanmaya elverişli sarp dağların fazla olması firar eden eşkıyaların barınıp, gizlenebilmeleri imkân sunmaktaydı. Bu sebeple bunların yakalanarak cezalandırılmaları pek kolay değildi. Ayrıca bunlar firsat buldukça korunaksız köylere saldırilar düzenleyerek her türlü ihtiyaçlarını kolayca temin etme imkânlarına sahiptiler. Diğer taraftan özellikle dağlık ve sarp alanlarda eşkıyalara yataklık eden köyler de mevcuttu. $\mathrm{O}$ yüzden güvenlik ortamının bozulmaması ięin bölge halkı, firar eden Alaaddin, oğulları ile eski Bitlis Han'ı ve avenelerini çevre köy, kasabalara sokmayacaklarına, içlerinden eşkıyaları destekleyecek olanları engelleyip, bu şekilde hareket edenleri yakalayıp devlet görevlilerine teslim edeceklerine ve devlete itaat edeceklerine dairsözvermişlerdir. Verdiklerisözün bozulmaması için de bir birlerine kefil olmuşlardı. Verdikleri sözün bozulma ihtimalini ortadan kaldırmak için de devlete teminat vermişlerdir. Eğer sözlerini tutmaz iseler Matbah-ı 'âmireye beş yüz kise akçe her kisede beş yüz kuruş vermeyi nezir etmişlerdi. Ahali ayrıca maddi açıdan verdikleri bu sözün yeterli görülmeyeceği düşüncesiyle eşkıyaya destek verdikleri takdirde bölgedeki hatırı sayılır kişilerin dahi devlet tarafından cezalandırılmasına razı olduklarını beyan etmişlerdir. Zira ahali, eğer eşkıyaya yardım ve yataklık yaparlarsa yüze gelür müte 'ayyin adamlarının devlet tarafından cezalandırılması hususunda da her biri taahhütte bulunmuştur ${ }^{39}$.

Alaaddin ve onun destekçisi Malazgirt sancakbeyi Nuh ve adamlarına ait olan bazı zeamet ve tımar toprakları eşkıyaların bir kısmının öldürülmesi ve diğer bir kısmının da firar etmesi sebebiyle boş kalmıştır. Bu toprakların güvenilir ve ehil kişilere verilmesi için merkezden Ekim 1754 tarihinde Erzurum valisi Çeteci Abdullah Paşa'ya bir ferman gönderilmiştir. Gönderilen ferman üzere eşkıyaların daha önce tasarrufunda olan Malazgirt sancağında 15 , Hınıs sancağında 11 ve Bitlis sancağında 16 ve toplamda 42 adet zeamet ve tımar toprağı başka kişilere tevcih edilmiştir ${ }^{40}$.

Firar eden eşkıya lideri Alaaddin ve oğulları ile diğer eşkıya reislerinin akıbeti hakkında bir bilgi bulunmamaktadır. Ancak Hınıs ve Tekman sancaklarını tasarruf eden Mahmud Bey'den razı olmayan Hınıs, Tekman ve Pasin kazası sakinlerinin Mahmud Bey'in görevden azledilmesi için merkeze sunmuş oldukları gerekçelerden biri Mahmud Bey'in Muşli Alaaddin oğullarıyla dahi macera-yı sâbıka ve husûmet-i kadîmleri olması Mütesellim Alaaddin'in oğullarının devlet tarafından affedilmiş olabileceğini göstermektedir. Nitekim payitaht ahalinin sunmuş olduğu gerekçeleri makul görmüş olmalı ki 1759 yılında Mahmud Bey’i görevden almış ve yerine Esedullah Bey'i atadığını bir fermanla yetkililere bildirmiştir ${ }^{41}$. Öte taraftan 1764 yılına ait başka bir belgede ise Alaaddin'in öldüğünü öğrenmekteyiz. Ancak şaki reisinin ne suretle vefat ettiği hakkında bir bilgi bulunmamaktadır. Yine aynı belgede Alaaddin oğlu Maksud'un Muş mütesellimi olduğunu görmekteyiz. Bu da Osmanlı Devleti'nin Alaaddin'in oğlunu affetmiş̧ olduğunu

39 BOA.C.DH.65.

40 BOA.C.DH.306

41 BOA.C.DH.102; Tahir Güngör, Vak'a-Nüvîs Hâkim Efendi Tarihi (Metin ve Tahlîl), Marmara Üniversitesi Sosyal Bilimler Enstitüsü (Basılmamış Doktora Tezi), İstanbul, 2014, s. 780. 
göstermektedir ${ }^{42}$.

Ne var ki Maksud da babası gibi rahat dứrmamıştır. Muş ve çevresinde eşkıyalık faaliyetlerinde bulunduğu gibi Çeteci Abdullah Paşa tarafından yıktırılan Mercimek Kalesi'ni de tekrardan imar ettirmiş ve burada ikamet etmeye başlamıştır. Ayrıca yine babası gibi kalenin etrafını kasaba şeklinde şenlendirmiştir. Diğer taraftan Ekrad taifesinden devlete muhalif olanları yanına toplayarak Hınıs ve çevresindeki yolları tutmuş, korunaksız gelip geçen yolcuların mallarını gasp etmiştir. Şaki reisi her geçen gün daha da güçlenmiştir. Hatta bölgeyi kontrol altına alabilecek bir güce ulaşmıştır. O yüzden eşkıya başının yakalanarak idam edilmesi ve Mercimek Kalesi'nin tekrardan tamir olmayacak bir şekilde yıktırılması içim Çeteci Abdullah Paşanın yeğini olan ${ }^{43}$ Kapıcı başlarından Çeteci Yeğen el-Hâc Hüseyin Bey görevlendirilmiştir ${ }^{44}$.

İran hudut hattına yakın bölgelerde etkili olan bu isyan ve eşkıyalık faaliyetlerinin bir an önce bastırılması sınır güvenliği açısından oldukça önemliydi. Zira İran'a yapılacak seferlerin güvenli bir şekilde sürdürülmesi için isyan girişiminde bulunanların cezalandırmaları icap etmekteydi. Nitekim eşkıya liderleri sürekli olarak devletin zayıf anını kollar, özellikle de savaş veya sefer dönemlerinde harekete geçerlerdii ${ }^{45}$. Bu sebeple Osmanlı Devleti isyanı bastırmak ve eşkıya liderinin bir an önce yakalanıp hak ettiği cezaya çaptırılması için Erzurum Valisi İbrahim Paşa'yı da görevlendirilmiştir. Ayrıca merkez, eşkıyaların faaliyet alanının daha çok Erzurum ve Van mıntıkaları olması nedeniyle Erzurum ve Van beylerbeylerinin eşkıyalık faaliyetleri hususunda irtibatlı olarak birlikte hareket etmelerini istenmiştir ${ }^{46}$.

\section{SONUÇ}

Çok eski dönemlerden itibaren önemli bir yerleşim merkezi olan Muş ve çevresi Osmanlı hâkimiyetine girdikten sonra devletin sınır güvenliği açısından stratejik bir öneme sahipti. Merkezden uzak İran'a yakın olan bu bölgede geniş ve korunmaya elverişli dağların olması eşkıyaların barınıp, gizlenebilecekleri imkânlar sağlamaktaydı. Bu yüzden Muş ve çevre şehirlerde isyan ve eşkıyalık olaylarına rastlamak mümkündü. Bitlis Han'ı tarafından Muş'a mütesellim olarak atanan Alaaddin Bey de 18. yüzyılın ortalarında devlete isyan etmiş ve eşkıyalık faaliyetlerinde bulunmuştur.

Eşkıya lideri ve avenesi özellikle Erzurum, Van, Muş ve Bitlis bölgesinde korunaksız köy ve nahiyelere saldırılar düzenleyerek halkın; mallarını, hayvanlarını, paralarını, eşyalarını gasp etmiştir. Kimi zaman da günahsız kişileri öldürmekten sakınmamıştır. Alaaddin'in girişmiş olduğu isyan ve eşkıyalık hareketine sınır boylarındaki bazı idareciler ve adamları da desteklemiştir. Eşkıya lideri üzerine gönderilecek askeri kuvvetlere karşı koyabilmek için Muş ve Bitlis dolaylarında savunma amaçlı kaleler, palangalar ve kuleler inşa ettirmiştir. Kalelere yeterli miktarda mühimmat ve çeşitli ebatlarda toplar bırakmış ve

43 Bekir Kütükoğlu, Çeşmî-Zâde Mustafa Reşîd-Çeşmî Zâde Tarihi, İstanbul,1993, s. 80.

44 BOA.C.DH.279.

45 Mücteba İlgürel, “Osmanlılar'da Eşkiyalık Hareketleri”, DIA, C.11, Ankara, 1995, s. 467.

46 BOA.C.DH.279. 
eşkıyalardan oluşan çok sayıda tüfekçiyi de buralara yerleştirmiştir. Bu suretle her geçen gün nüfus ve kuvvetini artıran Alaaddin devlet için büyük bir tehlike oluşturmuştur. Zira bölgede asayiş ve huzur ortamı kalmadığı gibi isyan ve eşkıyalık olayları Osmanlı Devleti'nin İran'a yönelik yapacağı seferlerde ordunun güvenliği açısından büyük bir tehlike arz etmekteydi. Bu sebeple isyan ve eşkıyalık olaylarının bir an önce bastırılması gerekmekteydi. Bu iş için payitaht, Erzurum valisi olan Çeteci Abdullah Paşa'yı görevlendirmiştir. Çeteci Abdullah Paşa eşkıyalara karşı verdiği mücadelede başarılı olmuştur. Bölgede eşkıyalara ait kale ve palangaları yıktırarak kullanılmaz hale getirmiştir. Fakat eşkıya liderlerinden Alaaddin ve oğulları ile Hakkâri bölgesinden Tatar Han ve eski Bitlis hanı Burhan ile Malazgirt Beyi Nuh, devlet kuvvetlerinden kaçmayı başarmışlardır. Bundan dolayı devlet bölge halkından, firar eden eşkıyaların çevre köy ve kasabalarda barındırılmaması, eşkıyalara yardım ve yataklık edilmemesi, yardım ve yataklık edenlerin de yakalanarak devlet görevlilerine teslim edilmesi hususunda söz almıştır. Verilen sözün tutulması içinde ahali bir birlerine kefil edilerek, maddi olarak nezre bağlanmıștır. Ayrıca ahali verilen sözü tutmadıkları takdirde içlerindeki hatırı sayılır kişilerin dahi devlet tarafından cezalandırılmasına razı olacaklarını kabul etmişlerdir.

İran sınır boyuna yakın bir mıntıkada ortaya çıkan bu isyan hareketinde eşkıya liderlerinin bozguna uğratılmasına rağmen yakalanamaması güvenlik ve huzur ortamının yeniden bozulmasına neden olabilirdi. Ayrıca bölgede firarilerin kışın dahi saklanması ve barınmasına imkân veren geniş ve korunaklı dağların olması eşkıya liderlerinin yakalanması açısından devlet görevlileri için büyük bir problemdi. Fakat İran'dan gelebilecek tehlikelere karşı bir an bölgede güvenlik ve huzur ortamının sağlanması gerekiyordu. Bu yüzden Osmanlı Devleti eşkıya lideri Alaaddin ve oğullarına bir takım mansıp veya makamlar vererek onları isyanlarından vazgeçirmiş olmalıdır. Ancak alınan bu geçici tedbirler isyan ve eşkıyalık olaylarını sonlandırmamıştır. Nitekim Muş mütesellimliği vazifesini elde eden Alaaddin'in oğlu Maksud da babası gibi isyan ve eşkıyalık olaylarına karışmıştır. Devlete muhalif kişileri etrafına toplayan eşkıya lideri babası döneminde isyan faaliyetlerinde kullanılan Mercimek Kalesi'ni yeniden inşa ettirmiş ve bölgedeki savunmasız ahaliye saldırarak mallarına ve canlarına kastetmiştir. Osmanlı-Devleti baba ve oğulun isyanıyla uzun süre uğraşmak zorunda kalmıştır. 


\section{KAYNAKÇA}

Başbakanlık Osmanlı Arşivi (BOA)

Cevdet Dâhiliye (C.DH.): 65, 98, 102, 194, 270, 279, 210, 306.

Cevdet Askeriye (C.AS.): 233.

Amedi Kalemi (A.AMD.) 8, 2.

Mühimme Defteri: (MHM.): 145, 153.

Tahrir Defteri: (TD.) 189.

Seyahatnameler

Evliya Çelebi b. Derviş Mehemmed Zilli, Evliya Çelebi Seyahatnâmesi, 4. Kitap, (Haz. Seyit Ali Kahraman-Yücel Dağl1), İstanbul 2001.

Araştırma ve İncelemeler

AGOSTON, Gabor, Barut, Top ve Tüfek Osmanli Imparatorluğu'nun Askeri Gücü ve Silah Sanayi, İstanbul, 2006.

AKDAĞ, Mustafa, "Genel Çizgileriyle XVII. Yüzyıl Türkiye Tarihi”, Ankara Üniversitesi Dil ve Tarih-Coğrafya Fakültesi Tarih Bölümü Tarih Araştırmaları Dergisi, 4/6-7, Ankara, 1966, s. 201-247.

AKDAĞ, Mustafa, Türkiye Halkının Dirlik ve Düzenlik Kavgası Celâli İsyanları, İstanbul, 2017.

AYDÜZ, Salim, Tophane-i Amire ve Top Döküm Teknolojisi, Ankara, 2006.

BARKEY, Karen, Eşkıyalar ve Devlet Osmanlı Tarzı Devlet Merkezleşmesi, (Çev. Zetnep Altok), İstanbul, 2011.

BAYRAK, Şaban, Anadolu'da Eşklyalık Olayları (XVIII. Yüzyılın İlk Yarısında 17001750), İstanbul, 2015.

ÇETIN, Cemal, "Kamu Düzeninde Alternatif Bir Yöntem: Nezir" Uluslararast Sosyal Araştırmalar Dergisi, 8/36, 2015, s: 287-310. 747.

DARKOT, Besim, "Muş", Meb. İslam Ansiklopedisi, C. 8, Eskişehir, 1997, s. 744-

DEMIRCI, Süleyman- ARSLAN, Hasan, Osmanlı Türkiye sinde Eşkıya, Devlet ve İsyan, İstanbul, 2012. 
GÖGER, Veysel, “Askerî Devrim Kuramı ve XVI. Yüzyıl Osmanlı Kale Kuşatmaları”, Dîvân: Disiplinlerarası Çalışmalar Dergisi, 22/42, İstanbul, 2017/1, s. 67-106.

GÖGER, Veysel, 16. Yüzyll Osmanlı Kale Kuşatmaları (Strateji, Taktik, Kuşatma Aşamaları ve Teknolojisi), Marmara Üniversitesi Türkiyat Araştırmaları Enstitüsü (Basılmamış Doktora Tezi), İstanbul, 2014.

GÜNGÖR, Tahir, Vak'a-Nüvîs Hâkim Efendi Tarihi (Metin ve Tahlîl), Marmara Üniversitesi Sosyal Bilimler Enstitüsü (Basılmamış Doktora Tezi), İstanbul, 2014.

İLGÜREL, Mücteba, “Osmanlılar'da Eşkiyalık Hareketleri”, DIA, C.11, İstanbul, 1995, s. 466-469.

KILIÇ, Orhan, "Muş Sancağı Dirlikleri”, Firat Üniversitesi Sosyal Bilimler Dergisi, 9/1, Elazı̆

KÜTÜKOĞLU, Bekir, Çeşmî-Zâde Mustafa Reşîd-Çeşmî Zâde Tarihi, İstanbul,1993.

ÖZCAN, Selim, "XVIII. Yüzyıl Canik (Samsun) Sancağında Eşkıyalık Hareketler”, Osmanlı'dan Günümüze Eşklyalık ve Terör, Editör, Osman Köse, Samsun, 2009.

ÖZKAYA, Yücel, “Mütesellim”, DIA, C. 32, İstanbul, 2006, s. 203-204.

PAKALIN, M. Zeki, Osmanlı Tarih Deyimleri ve Terimleri Sözlüğü, C. 3. İstanbul, 1983.

SAN, M. Salih, Doğu Anadolu ve Muş’un İzahlı Kronolojik Tarihi, Ankara, 1966.

SÖNMEZ, Mehmet Emin, "Muş İlinde Nüfus Hareketlerinin Nedenleri ve Sonuçları", Türk Coğrafya Dergisi, S. 55, İstanbul, 2010, s. 45-57.

ULUERLER, Sitk1, Osmanlı-Iran Sinır ve Aşiret (1800-1854), Ankara, 2015.

ÜNAL, Mehmet Ali, Osmanlı Tarih Sözlüğü, İstanbul, 2012. 